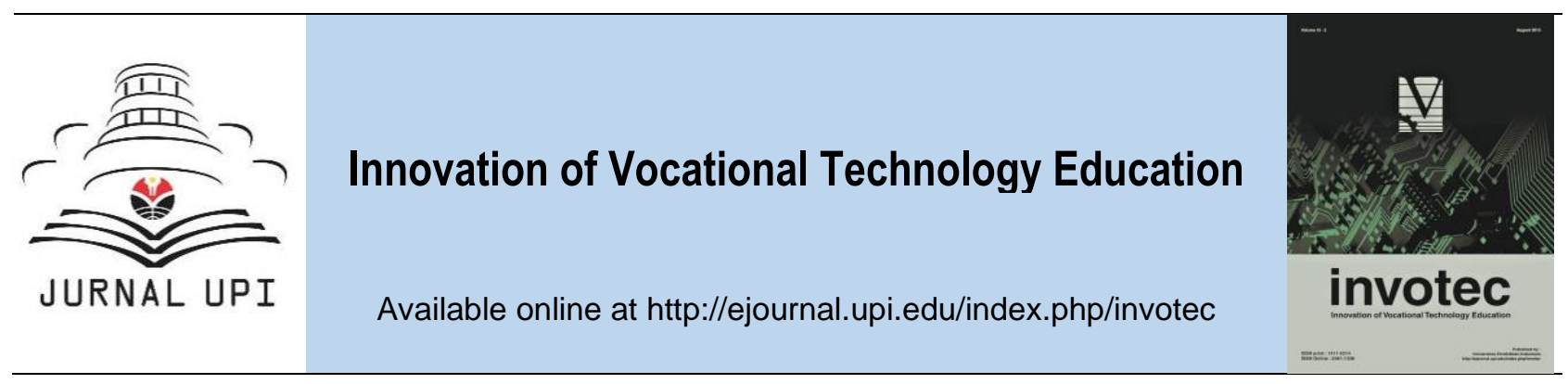

\title{
The Implementation of Work-Based Learning for the Development of Employability Skills of Vocational Secondary School Students Through Teamwork Activity
}

\author{
S. Subekti \\ Universitas Pendidikan Indonesia, Indonesia
}

\section{ARTICLE INFO}

Article history:

Received 25 November 2018

Received in revised form 20 January

2019

Accepted 18 February 2019

Available online 28 February 2019

Keywords:

teamwork,

employability skills,

work-based learning

Corresponding author:

Sri_subekti@upi.edu

\section{A B S T R A C T}

This study aims to investigate the contribution of teamwork activity through work-based learning to the development of employability skills of SMK (Vocational Secondary School) students. A survey method was employed in this study. The subject of this research are SMK students majoring in farm produce processing agribusiness with bakery competency in Garut. The findings of the study revealed that teamwork activity gives a positive contribution to employability skills of SMK students through the implementation of work-based learning. The contribution of work-based learning to employability skills in the aspect of teamwork is quite significant at the value of $63.5 \%$. The study lead to the conclusion that the implementation of teamwork activity through work-based learning can develop employability skills of SMK graduates.

\section{Introduction}

Countries in the world are racing towards increasing their innovative capabilities so as to allow them to survive and stay abreast of science, technology, economic and global business competition. This is evident from the innovation index of countries in the world grouped by the World Bank which revealed that there is a shift in the rank order over the past several years. Switzerland was the only country remained in the first rank from 2011 to 2017, followed by Sweden and the Netherlands in the second and the third ranks (Dutta, Lanvin, and Vincent, 2017). In the previous year (2016), the third rank was occupied by Britain but later it went down to rank 5th in 2017. In the meantime, the United States remained in the 4th rank in the years of 2016 and 2017.

This shift in innovation ranking does not only occur in the groups of high income countries, but also in other groups of countries. These include the group of low-medium income countries such as Indonesia, the Philippines, Cambodia, Vietnam, and Myanmar. Based on the World Bank's report, in 2017, Indonesia occupied the 87th position on the world innovation ranking (Table. 1) going up one level from 2016's ranking which occupied the 88th position with the score of 29.07. However, the rank went down if it is compared to the rank order in 2013 which occupied the 85th position (STRAED, 2016). Among the countries of South-East Asia and Oceania, Indonesia's innovation index in 2017 (Dutta, Lanvin, and Vincent, 2017) occupied the 14th position after the Philippines (ranked the 13th), Thailand (ranked the 10th), Malaysia (ranked the 8th) and Singapore (ranked the 1st). 
invotec XV:1 (2019) 35-42

Table 1 Global Innovation Index of countries in Southeast Asia 2017

\begin{tabular}{rlcccc}
\hline No. & \multicolumn{1}{c}{ Country } & Group & $\begin{array}{c}\text { World } \\
\text { Rank }\end{array}$ & $\begin{array}{c}\text { Southeast Asia - } \\
\text { Oceania Rank }\end{array}$ & $\begin{array}{c}\text { Score } \\
(0-100)\end{array}$ \\
\hline 1. & Singapore & High Income & 7 & 1 & 58.69 \\
2. & Malaysia & Up-Middle Income & 37 & 8 & 42.72 \\
3. & Thailand & Up-Middle Income & 51 & 10 & 37.57 \\
4. & Brunei Darussalam & High Income & 71 & 12 & 32.89 \\
5. & The Philippines & Low-Middle Income & 73 & 13 & 32.48 \\
6. & Indonesia & Low-Middle Income & 87 & 14 & 30.10 \\
7. & Cambodia & Low-Middle Income & 101 & 15 & 27.05 \\
\hline
\end{tabular}

(Source: Dutta, Lanvin, and Vincent, 2017, p. 14-19)

Meanwhile, the competitiveness index of Indonesia during the period of 2015-2016 (Figure 1) occupied the 37th rank with a score of 4.52 which dropped drastically in the period of 2016-2017 occupying the 41 st rank from 138 countries with a score of 4.52 . During the period of 2017-2018, the rank rose up to the 36 th of the 137 countries worldwide with a score of 4.68 .

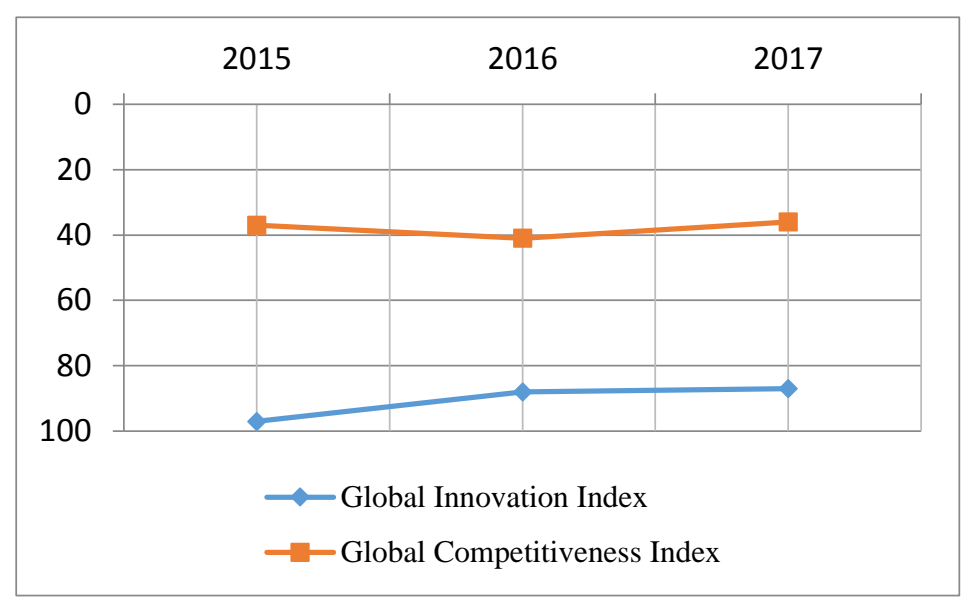

Figure 1. Indonesia's Global Innovation Index and Global Competitiveness Index 2015-2017 (Source: Dutta, S., Lanvin, B., and Vincent, S.W., 2017; Schwab, 2015; 2016; 2017)

This trend shows that Indonesia would still have to continue accelerating its innovative capabilities in the spheres of knowledge and technology, economy and business in order to be able to compete in the global economy as well as to increase the welfare of its citizens. These innovative and competitive capabilites are influenced by multifaceted factors such as political environment, education, research and development, infrastructure, investment, trade and market competition, workers' knowledge, knowledge absorption, and innovation network (Bresnahan and Yin, 2017). The high and low quality of these factors depends upon the quality of human resources of the state citizens which generally can be statistically seen from the human development index.

In 2017, the Human Development Index (HDI) of Indonesia was at the medium level. The development of Indonesia's HDI over the years, especially since 2010, is considered slow as indicated by an insignificant growth of only $0.78 \%$ (ILO, 2017, p. 3). One of the factors that slows down the growth of Human Development Index of Indonesia is the relatively low absorption of Indonesian professional labors, where in 2016 , it was only $10 \%$ on the professional engineering sectors and less than $25 \%$ on the business and trade sectors. The largest occupation position is on the agricultural sector which reached more than $30 \%$.

The unemployment rate is one of the factors that slow down the growth of human development index in Indonesia. The average unemployment rate in Indonesia falls under the category of low by $5.6 \%$ (ILO, 2017, p. 27). The figure is dominated by a group of teenagers (15-24 years) by $19.4 \%$. However, what strikes our attention regarding the unemployment rate in Indonesia in the year of 2016 is the high percentage of unemployed bachelor's degree graduates, followed by SMK graduates (ILO, 2017, p. 27). This seems as if it indicates the contradictory assumption that with the higher education level, getting a job will be much easier. In fact, in this education process, knowledge and work experiences are transferred to students as their capital to participate in the labor force. 
The education process applied at SMK is the process carried out in a planned manner so as to realize a convenient learning environment and a convenient learning process. Students are expected to actively develop their potentials in order to have religious spiritual strength, self-control, personality, intelligence, high moral standards as well as the skills that themselves, the community, the nation, and the state need. This process serves as the platform for students to acquire knowledge and experiences prior to entering and participating in a societal life. Through this education process, students foster their own ability and competency in different things that can benefit their lives in the future, including the knowledge and experiences for participation in the labor force (Calderdale, 2017).

One of the prerequisites for a person to be involved and participate in the labor force is the quality of his work capabilities and competencies suitable to the demands of labor force. Work capabilities and competencies are termed as employability skills (Robinson, 2000). A major concern faced by most of the entrepreneurs today is getting competent and skillful labors. Employability skills or readiness to work will help these prospective labors dominate the workplace at which they work. Employers need reliable and responsible workers who can solve problems and who have the social skills and attitudes to work together with other workers. High-performance workforce is needed for competitiveness in today's marketplace. Employees with these skills are in demand and are considered valuable human capital assets to companies.

To meet the demands of these work capabilities, each prospective worker is made ready in such a way through the process of education, training and work coaching. All of these should be applied to the process of education in vocational schools. The process of education implemented at SMK is directly linked to the industry and economy sectors with which this school has the role as the producer of educated labors. A major challenge that must be faced by SMK education system is the efforts to prepare prospective professional and educated manpower with high employability skills. Meanwhile, the fact has shown that there are still a large number of SMK graduates in Indonesia who are unemployed. This was triggered by the fact that their work skills/competencies have been incompatible with the demands of skills needed in the labor force. Therefore, there should be an effort to develop and improve the quality of students' learning process at SMK. Graduates that are produced must have competencies compatible with the rapidly evolving demands of the labor market. These should include the fostering of creation of academic skills, higher-order thinking skills, and personal qualities, so as to produce skilled labor candidates with adequate professional skills.

One of the efforts to realize these demands is by implementing a work-based learning (WBL) approach to students at SMK at which they are directed and coached in order to master the work competencies professionally. This learning approach places students as the subjects who actively explore experiences through various forms of professional work placements directly at the real work setting (Adams, 2015). WBL involves many diverse students who are actively doing the things they're learning about (and actively learning from this doing). You learn in your workplace and/or the classroom, further supported by electronic and mobile technologies. Increasingly communication between you, your tutors and your peers will be carried out online, and your university or college will offer you introductory support and skills sessions to make sure you get the most out of these new and developing technologies (Helyer, 2015, p. 2)

Work-based learning or an industrial work placement is a learning approach that serves as a competency development set for students to establish partnership cooperation directly with the organization. This learning approach directly involves students in an actual work setting. The students individually adapt to the learning approach through educational experiences, work experiences, and training. All of that can be optimally achieved by students if they have work passion and teamwork skills. In addition, they also have to understand other aspects related to basic academic competencies and thinking skill.

\section{Method}

A survey method was employed in this study. The data collected in the present study are natural data gathered from two SMKs serving as samples, namely SMKN 1 Cibadak and SMKN 1 Pacet with Vocational Programs of Farm Produce Processing Agribusiness (APHP) with bakery competency. The sample was determined using a purposive sampling technique. The students at both SMKs are on their industrial placement program. These SMKs have implemented work-based learning in preparing their students to jump into the working world. Regression analysis was 
employed as the analysis technique. The technique was used to investigate the extent of the effect of teamwork activity in the implementation of work-based learning on students' employability skills.

\section{Result and Discussion}

The results of this study indicated that there is a strong interrelationship between teamwork skill and the development of employability skills, especially of the educated labor candidates. The calculation result of coefficient of regression $(R)$ is 0.79 with $F$ coefficient at a confidence level of $95 \%$. The correlation value indicates that there is a strong and significant interrelationship between teamwork skill and students' employability skills. Teamwork skill has an impact on students' employability skills as indicated by the regression equation of $Y=5.102+0.083 \mathrm{X}$. This means that as teamwork skill increases, students' employability skills will also be positively affected. Teamwork skill in the workplace provides a positive contribution of as much as $63.5 \%$ towards the development of students' employability skills.

Speaking of the employability of Vocational School Graduates, the main concern has always been the creation of SMK graduates as employable skillful labors who prioritize skills to perform certain job types. In order to prepare employable graduates, to occupy employment opportunities either at the local, regional and international levels or to independently create employment opportunities, the employability skills need to be upgraded to the highest level.

In the current era of globalization, each and every state citizen is not only demanded to master the skills of reading, writing and calculating, but also to have a number of other competencies such as digital age literacy, inventive thinking skill, intellectual capital, interactive communication skill, social and personal skills, and also to be able to create a quality and up-to-date work (Kuat, 2017). These overall skills will principally promote the creation of employability skills for the prospective workforce or labors as invariably required by labor markets.

Employability skills are basic skills to obtain, to have, and to perform a job efficiently. These are the skills, attitudes, and actions that enable workers to get along with their fellow workers and supervisors and to make a sound critical decision. There are three types of skills that serve as the characteristics of employability skills. These include basic academic skills, higher-order thinking skills, and personal qualities.

Table 2. Three Skill Sets of Employability Skills

\begin{tabular}{llll}
\hline \multicolumn{1}{c}{$\begin{array}{c}\text { Basic Academic } \\
\text { Skills }\end{array}$} & \multicolumn{1}{c}{$\begin{array}{c}\text { Higher-Order } \\
\text { Thinking Skills }\end{array}$} & \multicolumn{2}{c}{ Personal Qualities } \\
\hline Reading & Learning & Responsible & Team Spirit \\
Writing & Reasoning & Self Confidence & $\begin{array}{l}\text { Punctual and } \\
\text { Efficient }\end{array}$ \\
Science & Thinking Creatively & Self-Control & Self-Directed \\
Math & Decission Making & Social Skills & $\begin{array}{l}\text { Good Work Attitude } \\
\text { Oral }\end{array}$ \\
$\begin{array}{l}\text { Communication } \\
\text { Listening }\end{array}$ & & Honest & Well Groomed \\
& & Have Integrity & Cooperative \\
& & Adaptable and & Self-Motivated \\
& & Fexible & \\
& & & Self-Management \\
\hline
\end{tabular}

Source: Robinson (2000, p. 2)

Although the level of academic skill is not strictly required by other types of work, basic academic skills remain essential in order to achieve a high level of work performance (Robinson, 2000). Each worker will need the skills to read and understand work instructions and the skills to respond to the instructions. Meanwhile, high thinking skill is more aimed at achieving success at work. The ability to think, to give reasons, and to make a decision are important aspects for workers in order to be able to carry out their work efficiently and for the development of their own selves. The implementation of thinking skill in the use of technology, instruments, tools and information systems will place the workers in a more qualified position. Hence, each company continually strives to improve its workers' quality through training programs in order to improve as well as to balance workers' basic academic skills and thinking skill. 
In multiple fields of work, it is difficult to effectively hire workers when they have low personal quality. Employees or workers with good personal quality will show confidence, honesty, and openness as well as demonstrate respect to co-workers, superiors, and others. They will show themselves as part of a group (a team) and will work in harmony with the team's work culture. Rather than blaming others when things go wrong, they are accountable for their actions. They also have the ability to set goals and priorities in their work and personal lives so that resources of time, money and other resources may be conserved and managed. These individuals practice good personal habits, come to work as scheduled, on time and dressed appropriately, and are agreeable to change when necessary (Robinson, 2000).

These are the aspects that serve as the characteristics as well as the indicators for employability skills that must be possessed by each prospective worker. Thus, the process of coaching and competence development of students at the education unit of SMK as the producer of prospective skilled and educated workers should always put graduates' employability skills as the main goal of education and learning process.

The efforts to develop students' employability skills on these vocational schools have been made through a number of education systems and learning approaches, one of which is a learning approach integrated to a job. This learning approach is termed as Work Integrated Learning (Cleary, et.al. 2007). In an effort to developing students' employability skills, one thing worth noting is that many students in developed industrial countries develop their expertise/skills through part-time works, voluntary works and community participation. Hence, it can be said that field work, industrybased learning, cooperative learning, and internship are the learning approaches that can be applied in order to develop SMK students' emplobility skills.

The relevance of work experience to learning programs has a high impact on employability skills as what has been frequently applied by business owners in the form of course design and delivery (Cleary, et.al., 2007). This proves that through work placement/experience, students can better understand and control their employability skills. The concept of Work-Based Learning is often misunderstood as Work-Related Learning. As a matter of fact, the two concepts differ distinctively where work-based learning constitutes a form of learning through a workplace, either in the form of work experience or work under guidance (work shadowing) in a certain period of time. The key characteristic of work-based learning is that the learning process takes place directly in the workplace or called as Workplace-Based Learning (PBTK).

The Work-Based Learning (WBL) approach is derived from the premise that a learning setting in the context of a real workplace does not only make academic learning easier to digest by the students, but also to improve engagement in the schooling of industry/workplaces. Thus, it can be said that the work-based learning is a learning system that describes a program where between education institutions and organizations or companies jointly design lessons at the workplace so that this program meets students' needs and contributes to the development of the company. Workbased learning provides opportunities for learning success. Engagement in their own learning through personal involvement in the real-life activities at the worksite, resilience developed by learning to work independently and with others to solve problems that have a number of viable solutions, and success in applying academic and technical knowledge in the workplace serve to increase student self-confidence and motivate them to pursue learning.

The most important thing to note in the implementation of work-based learning is the interrelationship between students' learning activities at the workplace and its educational curriculum. This interrelationship will significantly help to motivate students or to see how the skills they learn in the classroom needed in the workplace. This is the basis for implementing work-based learning to provide a learning experience to SMK students through a real work setting. It seems here that work-based learning is aimed to juxtapose learning activities to work. In addition to being a transition platform for students from school to the workplace, work-based learning is a means of knowledge development through a workplace with the involvement of the company.

The key characteristics of work-based learning approach encompass six elements, namely: (1) the relationship between partner/DUDI and education institutions which specifically aims to foster and reinforce learning; (2) students are engaged as workers; (3) programs in WBL follow those required in the workplace and students' needs; (4) the level of education in the program is formed after students have successfully acquired the recognized competence; (5) the learning project done in the workplace provides challenges to meet students' needs in the future as well as the company 
needs; and (6) educational institutions generate outputs based on the agreement in this program by adhering to the specified standards and levels (Siswanto, 2010).

From the six characteristics, the process of engaging students' in the workplace will provide valuable experience to students where they can be directly benefited from the applicable science and knowledge acquired in the classroom in order to meet the demands of the workplace. In addition, students will gain experiences and learn about how to deal with workplace situation, think creatively in order to improve quality of work and learn to make a decision in order to solve problems at work, instead of just the simulation they have at schools.

The ability to apply basic knowledge and science and to think creatively in making decisions and to solve problems that students face in the process of work-based learning will encourage and get them used to carrying out work efficiently so as to allow them to have sufficient work skills and meet the demands of the labor force. However, this effort will encounter hindrances. The greatest challenge faced by students in the process of learning through this work-based learning approach is the creation of a conducive work environment. In this case, students are confronted with a situation where they must be able to demonstrate high personal quality with the spirit of teamwork (group) for which the personality and behavior of their own and the employees/staffs in the workplace differ from each other. Here, students are required to be able to cooperate with others and to be able to appreciate personal values in the workplace and to achieve a high level of performance and productivity. These are the demands of social environment at the workplace for workers who are involved in it, including SMK students who are in the middle of work-based learning process.

A cooperative teamwork skill required in the labor force needs to be underscored and taught to students through a number of democratic approaches, so as to allow them to realize the significance of values, attitudes, and responsibility at work in order to establish personal quality as one of the important aspects of employability skills (Robinson, 2000). Employability skills can be fostered by employing a democratic approach so that students' awareness of values, attitudes, and worker's responsibilities is increased". Through this learning approach, students are coached and made accustomed to working in a team (group) in an actual work setting, to helping other workers, and to building cooperation in a different culture environment.

Work-based learning in Indonesia is known as an Industrial Placement. WBL is not merely a process of reading work or observing work (Helyer, 2015), but rather to place students to perform actual work activities. WBL involves many diverse students who are actively doing the things they're learning about (and actively learning from this doing). You learn in your workplace and/or the classroom, further supported by electronic and mobile technologies. Increasingly communication between you, your tutors and your peers will be carried out online, and your university or college will offer you introductory support and skills sessions to make sure you get the most out of these new and developing technologies (Helyer, 2015).

Work-based learning (WBL) or prakerin in Indonesian is a learning approach that serves as competency development set for students to establish partnership cooperation directly with the organization/company, directly involves students in an actual work setting and make students individually adaptable to learning through educational experiences, work experiences and training. All of that can be optimally achieved by students through having work passion and teamwork skills in addition to having other aspects related to basic academic competencies and thinking skills.

Teamwork is one of the sub aspects that serves as the characteristics of work-based learning approach, where the main benefit of this type of approach is to encourage students to reflect their work experiences and share them with other people. That is why this approach has high relevance for its implementation in the vocational education programs such as that in the vocational schools. Work-based learning: Having the skills to know how to learn at work is important in stimulating people to be positive about their own career development and to be positive about engaging in continuing formal vocational education and training (Sweet, 2014).

Teamwork activities in the workplace allow employees/staffs and the management to understand their respective needs, interests, and difficulties as well as to establish a work environment on the basis of partnership for the sake of mutual benefits. Through this partnership activity, each personnel involved in the company can increase his morals, motivation, and commitment which would subsequently increase his performance level. In addition, this cooperation will help boost innovation and willingness to disseminate information so that the work problems faced can be solved and at the same time better decisions can be made (Sudirwan and Pangestu, 2015). 
Therefore, the implementation of work-based learning in the students' learning process, especially at SMK, is of the utmost importance, where during the process, the program provides valuable experiences related to fostering cooperation in carrying out work in an actual work setting. This teamwork skill will drive the creation of a conducive work environment so that performance productivity can be established. This indicates that teamwork skill in the workplace environment is one of the components of personal quality that must be possessed and improved for the sake of the development of employability skills either of the prospective worker or the worker himself (Indrakusuma, 2016).

Work-based learning provides substantial opportunities for students to work in a team and to make managerial decisions. With respect to teamwork skill, it is highlighted that students getting to learn to work together as a team is of utmost importance. (Alfeld, et.al., 2013). You can't work in almost any job without being able to understand what your contribution is anywhere along the pipeline and what happens if your part is broken".

\section{Conclusion}

The findings of our study lead to the conclusion that work-based learning provides an effect on and a contribution to the teamwork skills and employability skills of SMK students. Such skills are one of the prerequisites for a person to improve skills quality and work competency in compliance with the demands of labor force. These work skills and work competency are termed as employability skills. The efforts to prepare prospective professional and educated labors with high employability skills can be done by implementing work-based learning strategy and approach. This learning approach places students as the subjects who actively explore experiences through various forms of professional work placements at a real work setting.

\section{References}

Adams, D. (2015). The Work-Based Learning Student Handbook Review. WBL e-journal International. 5 (1), 117-118.

Alfeld, C., et. al. (2013). Work Based Learning Oppotunities for High School Sudents. Louisville: National Research Center for Career and Technical Education University of Louisville.

Bresnahan, T. and Yin, P. L. (2017). Adoption of New Information and Communications Technologies in the Workplace Today. The National Bureau of Economic Research.

Calderdale. (2017). Higher Education Work-Based Learning Handbook for Students 2016-2017. Calderdale College.

Cleary, M., et. al. (2007). Graduate Employability Skills-Prepared for The Business, Industry, and Higher Education Collaboration Council. Melbourne: Departement of Education, Science and Training Comonwealth of Australia.

Dutta, S., Lanvin, B., and Vincent, S.W. (Eds.). (2017). The Global Innovation Index 2017-Innovation Feeding The World. Tenth edition. Geneva: Cornell University, INSEAD, and the World Intellectual Property Organization.

Helyer, R. (2015). Adapting to Higher Education: Academic Skills. In Ruth Helyer. The Work-Based Learning Student Handbook. $2^{\text {nd }}$ edition. New York: Palgrave Macmillan.

ILO. (2017). Indonesia Jobs Outlook 2017-Harnessing Technology for Growth and Job Creation. Jakarta: International Labour Office.

Indrakusuma, A. H. (2016). Model Work-Based Learning sebagai Kemitraan untuk Persiapan Lulusan Perguruan Tinggi Memasuki Dunia Kerja. Jurnal IImiah Pendidikan Informatika. 1(1), 31-34. 
Kuat, T. (2017). Implementasi Employability Skills pada SMK Program Keahlian Akuntansi Bidang Keahlian Bisnis Manajemen. Jurnal Pendidikan IImu Sosial. 27 (2), 1-9.

Robinson, J. P. (2000) What are Employability Skills? The Workplace. 1(3), 1-3.

Schwab, K. (2015). The Global Competitiveness Report 2015-2016. Geneva: World Economic Forum.

Schwab, K. (2016). The Global Competitiveness Report 2016-2017. Geneva: World Economic Forum.

Schwab, K. (2017). The Global Competitiveness Report 2017-2018. Geneva: World Economic Forum.

Siswanto, B. T. (2010). Pengembangan Program Penyelenggaraan Work-Based Learning pada Pendidikan Vokasi Diploma III Otomotif. Proceeding Seminar Internasional Peran LPTK dalam Pengembangan Pendidikan Vokasi di Indonesia. Aptekindo, 301-204.

STRAED. (2016). The Global Innovation Index (GII) 2013-2016. Taguig City: Department of Science and Technology Bicutan.

Sudirwan, J. and Pangestu, H. (2015). Kesiapan Dosen untuk Mengembangkan Keterampilan Kerja, Studi Kasus Pada Binus University. Paper dalam Seminar Nasional Teknologi Informasi dan Komunikasi 2015 (SENTIKA 2015) Yogyakarta tanggal 28 Maret 2015.

Sweet, R. (2014). Work Based Learning: Why? How? in Richard Sweet. Revisiting Global Trend in TVET. UNESCO-UNEVOC. 